\title{
Internalisation Theory and Outward Direct Investment by Emerging Market Multinationals
}

\author{
Peter J. Buckley ${ }^{1}$ (D)
}

Received: 6 April 2017/Accepted: 28 June 2017/Published online: 4 August 2017

(C) The Author(s) 2017. This article is an open access publication

\begin{abstract}
The rise of multinational enterprises from emerging countries (EMNEs) poses an important test for theories of the multinational enterprise such as internalisation theory. It has been contended that new phenomena need new theory. This paper proposes that internalisation theory is appropriate to analyse EMNEs. This paper examines four approaches to EMNEs-international investment strategies, domestic market imperfections, international corporate networks and domestic institutions - and three case studies-Chinese outward FDI, Indian foreign acquisitions and investment in tax havens - to show the enduring relevance and predictive power of internalisation theory. This analysis encompasses many other approaches as special cases of internalisation theory. The use of internalisation theory to analyse EMNEs is to be commended, not only because of its theoretical inclusivity, but also because it has the ability to connect and to explain seemingly desperate phenomena.
\end{abstract}

Keywords Multinational enterprises $\cdot$ Emerging markets $\cdot$ Internalisation theory · International investment strategies - International corporate networks · International mergers and acquisitions

\section{Introduction}

This paper examines four research approaches to the rise of emerging market multinational enterprises-international investment strategies, domestic (capital) market imperfections, international corporate networks (including business groups) and the role of domestic institutions and shows how each is related to internalisation

Peter J. Buckley

pjb@lubs.leeds.ac.uk

1 Leeds University Business School, University of Leeds, Leeds, UK 
theory. It then examines three empirical manifestations of EMNEs - the case of Chinese EMNEs, foreign acquisitions by Indian MNEs and the involvement of EMNEs in tax havens, using the four key strands of theory. The relevance and predictive power of internalisation theory is shown throughout.

\subsection{Research Approaches to Emerging Market Multinational Enterprises}

There are four research approaches to the explanation of the rise of outward foreign direct investment (OFDI) by emerging market multinational enterprises (EMNEs). These are: (1) a focus on the international investment strategy of EMNEs, (2) the role of domestic (capital) market imperfections, (3) the role of international business networks and (4) the effect of domestic institutions. All four have implications for, and derivations of, internalisation theory embedded in them.

This paper starts with a consistent and theoretically grounded approach based on internalization theory (Buckley and Casson 1976; Buckley 2014). In fact a "purist", "stripped-down" version of the theory is utilized in contrast, starkly, with the RBV's emphasis on 'competitive advantages' 'ownership advantages' (Dunning 2000) or 'dynamic capabilities' (Pitelis and Teece 2010; Teece 2003, 2012). This version relies on two explanatory factors-locational determinants (L) and internalisation (or externalisation) decisions (I). The interaction of these two variable sets determines the location and mode of operation of the firm-recognising that the combination of the two is not necessarily automatic (Hennart 2009). Locational determinants are either market based or resource driven, where resources include natural resources, labour or strategic assets. The multinational enterprise (MNE) is conceived as a vehicle originating, controlling and extending a network of activities where intangible, or mobile resources (mainly knowledge and information) is circulated to combine with fixed points given by locationally fixed resources (L). This provides an example of the use of "Ockham's razor" in reducing the number of entities necessary to achieve explanatory value (compare the myriad variables adduced in Deng's 2012 survey). It should also help researchers to focus on how far new theory (and explanatory variables) are necessary to explain outward foreign direct investment from China and other emerging source countries. A similar approach is taken by Verbeke and Kano (2015) who illustrate internalisation theory from a historical perspective and use case study evidence on EMNEs.

Following a discussion of the four research approaches, the paper applies the analysis based on these four rubrics to the case of outward foreign direct investment from China, Indian foreign acquisitions and tax haven investment by EMNEs.

\section{Approach 1: International Investment Strategy}

Papers such as (Wu and Chen 2001; Wu and Sia 2002), among others, argue that market-seeking motives have predominantly driven historical investment behaviour of Chinese MNEs, especially during the 1980s. This investment behaviour was conducted mainly to raise familiarity with international market behaviour and requirements, to collect market information for subsequent investments and exports, 
to circumvent trade barriers, and, eventually, to facilitate exports of Chinese domestic firms. During the 1990s, the strategic focus of market-seeking FDI shifted from these trade supporting, defensive functions to a more offensive approach (Buckley et al. 2008; Liu et al. 2005). Further push factors were the inadequate distribution and logistics networks and regional protectionism in domestic markets, which became highly competitive and saturated in some sectors, especially after China's accession to the World Trade Organization (WTO) in 2001 (Sauvant 2005; Zeng and Williamson 2007; Boisot and Meyer 2008). Market seeking investment behaviour has seen Chinese firms increasingly invest, for example, in developing countries across Asia and Africa (Pangarkar and Yuan 2009; Deng 2004; Zhan 1995) also highlight asset-seeking strategies as important drivers for Chinese OFDI in developed countries. This is reflected in, inter alia, acquisitions and the establishment of R\&D affiliates in Europe. The efficiency-seeking motive has been argued to be only a minor driver of Chinese OFDI in the 1980s and 1990s (Buckley et al. 2007), although it is arguable that, with the rise of Chinese labour costs, the efficiency motive is beginning to become significant.

In internalisation theory the firm can continuously choose its foreign operational mode (including entry mode to new markets). The relative costs and benefits of foreign operation modes vary over time and lead to a dynamics of choice. Internalisation theory includes the hazards of doing business in foreign locations including the liability of foreignness and risks of dissipation of knowledge assets.

Market imperfections in international intermediate product markets are necessary and sufficient to explain the existence of MNEs (Eden and Dai 2010, p. 18).

In order to capture the rent from innovation (to appropriate the returns), firms (MNEs) need to integrate the output of innovation with marketing and production (Buckley and Casson 1976). Thus, FDI, with its associated control (of knowledge) is needed to protect the value of 'the patent' (the internal Intellectual Property Rights). FDI is therefore a proxy for the supporting assets needed to protect and appropriate the value of the original innovation (note the similarity of the argument with Aliber (1970, 1971).

In contrast, firm specific advantages are defined in the short run (against contemporary competitors) and ignore difficulties of invitation dissipation and misidentification of "the advantage". FSAs are necessarily temporary and the analysis underestimates the risks and costs of protection of intellectual property that is built into internalisation theory.

The difference from the transaction cost economics of Williamson $(1975,1985)$ is that internalisation theory concentrates on external market imperfections, TCE focuses on small numbers conditions and opportunism (Lundan 2010, p. 53) which can be incorporated as special cases in general internalisation theory. Internalisation theory does not include behavioural assumptions such as opportunistic behaviour, in the general case, which makes it more attractive - and more general.

It is arguable that opportunism "self-seeking behaviour with guile" is more prevalent in EMNEs than other types of multinationals. This is based on the short tenure of managers in SOEs, on corrupt behaviour arising from certain countries' management mores and possibly on lassitude in corporate governance standards in emerging countries. It is doubtful that opportunism per se can be a sustainable long 
term explanation for outward investment, although it might have some localised significance. The burden of proof rests with those who utilise such an explanation.

Internalisation theory incorporates home (source) country factors by examining those intermediate goods and services markets which firms from a particular home market are most likely to internalise. Where markets are internalised across national frontiers, then MNEs are created. Thus the national firm is a special case of the MNE where only domestic intermediate goods and services markets are internalised. Home country context thus plays a major role in determining the growth of MNE and their associated foreign direct investments (Buckley and Casson 1976).

In the specific case of emerging countries, the crucial imperfections are often in the financial markets (Buckley et al. 2007; Morck et al. 2008). State owned enterprises (SOEs) often have access to capital at below market cost rates, through soft loans, channelling of state funds or dominance in the financial markets. Conglomerate firms (as in India) may use their internal capital market to channel funds to the potential foreign investor units and family firms may subsidise outward FDI. The motive for these internal subsidies may vary-it may be a version of 'capital flight', it may be to avoid restrictions at home, it may involve prestige or vanity projects or it may be a roundabout means of improving the firm's competitive position at home (Witt and Lewin 2007). More conventionally, it may represent strategic asset acquisition [one of the four key motives to invest abroad along with market seeking, resource seeking or improved efficiency (cost driven)].

Home country context matters not only in the ability to undertake FDI, but also in its direction. MNEs are influenced by cultural links and barriers (Johanson and Vahlne 1977; Johanson and Wiedersheim-Paul 1975) by the relative costs and liabilities of foreignness (Zaheer 1995), by perceptions of risks (Liesch et al. 2011; Buckley et al. 2016) and by relative costs - all of which depend on the home country location. Source government institutions can also have an effect-it is frequently argued that China's OFDI is induced by Government policy (Buckley et al. 2007). This institutional push can range from outright government dictat to simply knowledge sharing among current and potential direct foreign investors. A 'bandwagon' or follow my leader effect (Knickerbocker 1973) may occur naturally through imitative behaviour or may be induced by Government policy (the 'Go Global' phase of Chinese government policy for instance) (Buckley et al. 2007).

The extent, direction, timing and mode of OFDI are therefore partially determined by source country conditions. However, to call these 'Country specific advantages' is misleading. The above analysis has shown that the factors that determine OFDI are selective, and discriminatory among firms - they do not apply to all firms resident in that country equally_indeed many elements are deliberately targeted at a few privileged firms only: presence in the country does not qualify firms for 'CSAs'. National policy is important, but so too are the existence of firms with the capacity to conduct OFDI-this is constrained by access to finance, but also to managerial capacity.

Studies such as Buckley et al. (2007) find that Chinese outward direct investment follows the same motives that govern MNEs in general. (Natural) resource seeking, market seeking strategic asset seeking (particularly in acquisitions) and, to a limited and sector specific extent, efficiency seeking all feature in explanations of outward 
FDI by EMNEs (Dunning and Lundan 2008). To some extent this has to be nuanced by the particular circumstances of the host and source countries and also the sector in which the investment takes place, but other competing motives, such as political direction appear to have a more limited role than the strategic business motives. (Cuervo-Cazurra and Ramamurti 2014).

The ability to undertake OFDI is not the same as the ability to make the subsequent investment successful. Conducting an acquisition is not the same as successful post-acquisition performance, nor of conducting a take-over at the optimal price. Subsidised financial resources and ignorance of risk may allow the act of FDI, but may be inimical to its ultimate success or even survival. In the context of studies of OFDI by EMNEs, we lack long run studies of the efficiency of entry or ultimate success and survival. Partly, this is because of the lack of compelling evidence and partly because of the recency of most investment by EMNEs.

As reported by Godley (2014, p. 32); Pettis (2013) estimates that the Chinese Government's policy of 'financial repression' on the household sector, restricting the interest rate on deposits and savings accounts to subsidise the borrowing of industrial sectors, transferred of the order of 5-6\% of Chinese GDP to firms. This permanent subsidy stream enabled Chinese firms to acquire global competitive advantage but not (yet) economically sustainable competitiveness. The process is, however, opaque.

This is an example of the Gerschenkron (1962) framework where firms build competitive advantage by substituting internal markets for imperfect external markets or creating new internal markets. Market substitution is illustrated by the original Gerschenkron application, to Germany (mid nineteen to early twentieth centuries) where privileged "universal banks" channelled investment and information to private sector firms and efficiently coordinated their activity. Buckley et al. provide evidence of the creation of "internal banks" within large Chinese firms (such as Sinochem Group) with manufacturing firms being granted the right to start and own banks (2007, p. 502). Similarly, Japanese MNCs in the twentieth century built strong internal labour markets to substitute for weak national labour markets and thereby created a corporate culture that supported flexible manufacturing systems and the integration of $\mathrm{R} \& \mathrm{D}$, production and marketing within innovating firms. An example of market creation is Greek business groups before 1914 "headquartered in a handful of Ionian islands" (Godley 2014, p. 39) that created a market in global shipping information because of their strong cultural ties. All these examples of internalisation of external markets (taken from Godley 2014) allowed sustainable international competitive advantages to be built by the participating firms.

The original internalisation of markets is a home country based phenomenon and has been mistakenly identified as a "Country specific advantage" (CSA), thus extracting from the general process a special case of the internalisation theory of the MNE (Buckley and Casson 1976). It is however, only part of that process because the firm also has to have the ability to project the advantages of internalisation internationally. In the case of cheap capital, the original projection is often through acquisition. The longer term test here is whether post-acquisition integration of the 
target company can be successfully undertaken. Transfer of labour market advantages depends on the institutional configuration of foreign labour markets. The international transfer of internalised information markets is the classic application of the (Buckley and Casson 1976) theory of internationalisation-the "special case" of internalisation of information (or knowledge) intensive markets.

This analysis points out the difference between the ability to invest abroad (particularly by acquisition) and the ability to sustain that investment and to integrate international activities so as to become a sustainable (profitable) multinational enterprise.

There are two other factors that are important in examining the international investment strategy of EMNEs - the 'bundling' or counterpart strategy introduced by (Hennart 2009) and the longstanding importance of cultural links and barriers. Hennart's key point (Hennart 2009; Hennart et al. 2014) is that so-called "Country Specific Advantages" (CSAs) are not freely available in the host countryparticularly not to foreign entrants-and that accessing the advantages of a particular host country location requires investment in skills or, intrinsic partnering and accessing skills in the entrant firm. This moves the argument on to evaluating the skills of particular EMNEs and possibly EMNEs from given source countries who may be alleged to have perfected or acquired such skills (Hennart 2012). These skills may be transferable within the (E)MNE but this require supporting theoretical hypotheses and practical empirical investigation before these arguments can be adopted. Cultural links and barriers are clearly differential by source and host country, by industry, sector and mode of operation and require conceptual and empirical clarity before they can be accepted as "determinants" of the scope, nature and direction of OFDI by EMNEs (Buckley et al. 2007; Johanson and Vahlne 1977; Johanson and Wiedersheim-Paul 1975; Zaheer 1995).

Hennart's $(2009,2012)$ transaction cost/internalisation approach moves away from a purely firm-centred focus and embeds the analysis in markets and institutions (including Governments). He is correct in that the strategic asset seeking motive requires re-theorising. The best approach is to focus on the internalisation of key markets and the structure of market imperfections. By examining the market for corporate control, we can contrast the efficacy of internalising control of the whole firm, as a bundle of pre-packaged assets, with internalisation of individual markets in assets such as technology, management and distribution. The first alternative is acquisition of the firm. Here some emerging market firms, such as Chinese firms choose acquisition in order to digest the whole firm-and with it, key technologies and management. Unusually, Chinese MNEs retain the existing management and often leave the acquired firm intact as an independent entity. This is in contrast with "Western" MNEs who seek synergy by breaking up the pre-existing management and integrating the acquired unit fully into global operations. The specialised nature of Western firms (in contrast to many Emerging market firms that are widely diversified) enables EMNEs to utilise the sophisticated Western market for corporate control to 'pick and choose' suitable targets (Buckley et al. 2010, 2011, 2014a, b).

We should not forget that the observed outcome of OFDI decisions by EMNEs is constrained by the policies of host countries. Chinese MNEs may be the most 
constrained by regulatory action-in the US, for instance, the Committee on Foreign Investment in the United States (CFIUS) is particularly severe on potential investment from China: for (allegedly) strategic reasons. Host country regulatory and approvals bodies may discriminate against takeovers-biasing FDI towards greenfield ventures (and potentially joint ownership as a substitute for acquisition).

\section{Approach 2: Domestic Capital Market Imperfections}

All multinationals respond to their domestic circumstances and therefore have different trajectories, sectoral make-up and motives based on this starting endowment. (Buckley et al. 2007) posit that Chinese firms have enjoyed privileged access to capital on preferential terms because of domestic capital market imperfections. Such imperfections originate from a number of sources, including soft budget constraints, an inefficient banking system, intrabusiness group crosssubsidization, and personal capital. (Shiria 2002) showed that larger, older, and less profitable Chinese firms in particular have received bank loans on attractive terms from Chinese state-owned banks. Preferential treatment and access to cheap money can spur Chinese firms to invest abroad, because abundant funding can (1) reduce the commercial and financial risks connected to overseas investment projects, (2) mitigate disadvantages of "home country embeddedness" and institutional distance (cf. Makino et al. 2002), and (3) enable the subsidization of potentially less profitable technology- and brand-seeking ventures, especially in industrialized countries, which might otherwise threaten the long-term survival of the investing firm. In the eclectic theory, the ability of firms to derive benefits from such capital market imperfections constitutes an ownership-specific (O) advantage, which may enable them to out-compete rival foreign firms (Dunning and Lundan 2008).

It is notable that the Resource Based View of the firm is based on the internalisation of imperfect external factor markets. (Barney 1986) states that a necessary condition for competitive advantage is the existence of imperfect factor markets so that the firm can appropriate the difference between the price of the factor and its value to the firm. Its future strategy then is predicated on the creation and protection of rents by erecting barriers that are essentially informational in nature- "isolating mechanisms" in (Rumelt's 1984) terms. This brings the resource based view very close to internalisation theory (Buckley 2016).

Internalisation theory argues that imperfections in domestic markets-particularly capital markets-enable EMNEs to attract capital at less than equilibrium market rates. These "subsidies", intended or not, thus fuel the ability of EMNEs to purchase foreign companies or to enter by greenfield methods and amass the assets necessary more easily than foreign competitors. The first effect is the more obvious.

These imperfections are context (and therefore often host country) specific. Referring to Table 3, state owned EMNEs (and state associated firms) may have access to capital via soft budget constraints or state loans at below market rates. Inefficient banking systems may make soft loans to (potential) outward investors either as a matter of deliberate policy or through inefficiency. Conglomerate firms (world stage aspirants or global niche players) may operate an internal market for 
capital that effectively subsidies divisions or units that invest abroad. This mechanism may be operative in Indian MNEs takeovers in advanced countries and in certain Chinese firms (see Liu and Li 2002 on Haier). Finally, in entrepreneurial and family businesses, family members may make cheap loans to the foreign investors in the family. In all these categories, there may be elements of capital flight motives to move money to more secure locations and more secure assets (as for example in overinvestment in real estate).

\section{Approach 3: International Corporate Networks}

(Buckley et al. 2007) argue that Chinese MNEs are able to benefit from access to international business and social networks in foreign markets. Networks can be defined as a "set of high-trust relationships which either directly or indirectly link together everyone in a social group" for the recursive exchange of information, services, and goods (Casson 1997, p. 813). Such networks represent the social capital (or relational capital) of a firm. They can enable companies to internationalize or foster the internationalization process by facilitating the exploitation of business opportunities, promoting the dissemination of information between actors previously unknown to each other, lowering transaction costs (Aharoni 1966; Chen and Chen 1998; Johanson and Vahlne 2003), and creating or augmenting their competitive advantages (Hitt et al. 2002). Access to a network may also help firms raise capital, recruit employees, and connect to further businesses once the foreign affiliate is established (Hitt et al. 2002). Again, the ability to access and tap these types of networks may constitute an O-advantage for the internationalizing firm (Dunning and Lundan 2008). This thinking indicates that Chinese firms will not necessarily invest to the most proximate country but, rather, to the location with the more pronounced and accessible networks and where the firm can quickly become an insider (Johanson and Vahlne 2009). Indeed, in the case of China, members of the social network formed by the Overseas Chinese Diaspora, now the world's largest transnational ethnic network (Central Intelligence Agency 2017), have been encouraged by the Chinese government to return and establish companies in China. This network has been shown in the past to foster economic exchanges (Sung 1996; Saxenian 2002). Business networks have recently become increasingly significant for Chinese firms as a consequence of China's reintegration into the world economy and its interactions with foreign businesses (in China or through exports) and with business facilitators [such as consultancies and investment promotion agencies (IPAs)] from other countries that are increasingly establishing a presence in China with a view to assisting the internationalizing of Chinese firms, albeit often with certain investment destinations at home in mind (cf. Welch and Luostarinen 1993).

Firms are surrounded by markets and can be described as "islands of planning in seas of markets" (Robertson 1923). Their external boundary relations and relationships are interfaces with markets, yes, but also with the other firms operating in those markets-suppliers, distributors, agents, partners. Some firms also interact with individuals and households as customers, rather than other firms. These network relationships are complex and bargaining and negotiation, as well as 
"pure" market interactions surround the firm. This is the essence of the networkand theorising around network relationships is critical, given that multinationals are often focal [or flagship (Rugman and D'Cruz 2000) or orchestrating (Hinterhuber 2002)] firms, central to a "global factory" structure that involves a constellation of independent firms (Buckley 2011a, b; Buckley and Ghauri 2004; Eriksson et al. 2014). These dynamically shifting boundaries are a major focus of international business research (Hennart 2009) and have been since the beginning of the subject (Casson 1979; Caves 1980). In the internalisation approach, networks emerge as coordinating mechanisms-like the firm and the market (Casson 1987). Crucial issues within networks are control of information and-in production and particularly service networks - control of quality. Networks provide a context for the exercise of entrepreneurial judgement in a volatile environment and thus provide a background for the analysis of entrepreneurship, culture and trust (Buckley and Casson 1988). This is the background for the global systems view of international business (Casson 2000; Buckley and Hashai 2004; Buckley 2016).

A particularly strong association is often asserted between membership of business groups and EMNEs (for a summary of this literature see Pedersen and Stucci 2014). Membership of such groups can promote trust and reduce transactions costs (Buckley and Casson 1988), mitigate a lack of international experience, and generate network connections, including with financing institutions such as banks, governments and up and down the supply chain. Information, finance, managerial skill and contacts are thus key advantages of belonging to such groups. The downside are the often opaque nature of the network (Buckley 2004) and involvement within efficient and corrupt bodies leading to discrimination by the network in favour of 'members' which can lead to unfavourable regulatory and consumer reaction.

As we shall see below (Sect. 2.3) business group affiliation is most frequently associated with Indian and South East Asian firms in the context of EMNEs (and of course Japan and Korea in OECD countries). However, China too has an institutional background that draws on business groups-often State created as 'trial business groups' or 'national teams' (Nolan 2001). These groups are often in receipt of special treatment from both Central and Provincial Governments including tax advantages, subsidies and accelerated approval for foreign direct investment (Buckley et al. 2007; Yiu et al. 2013). This raises the issue of political goals supplementing, or even replacing, economic motives in OFDI and the perverse attitude to risk suggested by Buckley et al. 2007 may be a reflection of Chinese groups seeking political gains from investing in "risky" countriesalthough these are also avoided by competitors from the West and therefore may be (also) economically rational investments-often with higher risk goes higher returns. The spreading of risk through a group structure is a possible further link between business group affiliation and higher risk OFDI locations.

Potential sources of gain from network firms include the following; (1) economies of scale; these must be at the level of the firm rather than the plant; (2) economies of scope; utilising versatile resources in different contexts as in information sharing and pooling. The collection and use of honest, reliable information is a key feature here. Price distortions favour internalisation so that 
Table 1 Benefits and costs of different types of network configuration Source: Buckley (2004), p. 260

\begin{tabular}{|c|c|c|}
\hline & Benefit of open, and transparent & Cost of closed and opaque \\
\hline Horizontal & Learning/diffusion & Collusion on price \\
\hline Vertical & $\begin{array}{l}\text { Co-ordination of intermediate product markets and } \\
\text { upstream/downstream investments }\end{array}$ & $\begin{array}{l}\text { Vertical integration as } \\
\text { barrier to entry }\end{array}$ \\
\hline
\end{tabular}

honesty or moral behaviour is a substitute for direct ownership. Complementary assets where barriers to internalisation exist gives rise to various forms of cooperation across the boundaries of the firm. The possibilities include: (a) vertical networks which enhance specialisation and coordination without the costs of full internalisation; (b) political networks which reduce the unfavourable effects of political discrimination. (This represents the creation of islands of high trust in low trust societies and gives rise in its malign form to 'Croneyism'); (c) Intermediation; where networks provide trust, services or quality assurance; (d) collusion in search of rent enhancement and the circulation of finance; (e) risk reduction as expressed in diversification. This includes political risk reduction (techniques vary from transfer pricing to money laundering) and the provision of collective security (for instance, in response to a threat to a particular ethnic group).

Table 1 examines the benefits of open and transparent groups contrasted with the costs of closed and opaque groups. Moving from open to closed groups, horizontal learning diffusion becomes collusion on price and co-ordination benefits of upstream/downstream co-ordination solidify into vertical integration as a barrier of entry.

Vertical, open, transparent, type 1 network firms may arise where relational contracts exist to trade off price sensitivity against quality assurance. Relational contracts between specialist operators in the network are a form of mutual insurance, in particular relation to the quality of the linking supply of intermediate goods. In return for forbearance on cheating, a higher price for the intermediate good may prevail, but where price pressures do not predominate (e.g., where consumers will pay for assured quality), such a network may be optimal. Type 1 networks also arise as a means of diffusing technology. This enables adaptation of the technology and also incremental improvement (possibly, through 'reverse engineering' and pirating of hard-to-patent technology such as designs).

The second type of network firm (closed and opaque) may be a "pragmatic response to regulatory distortion" ${ }^{1}$ (Buckley and Casson 1988, p. 53). Both (Jesudason 1989) and (Yoshihara 1988) point to the history of government intervention as a key element in the growth of Chinese network firms. Yoshihara refers repeatedly to "the low quality of government intervention" (1998, p. 131). Initially, Chinese capital was excluded by the colonial governments' discriminatory grants of monopoly and licences. This created a parallel network of Chinese companies (Buckley and Mirza 1988). Post-colonial indigenisation and

\footnotetext{
1 This phrase was originally used to refer to the existence of a joint venture.
} 
discrimination against imports and foreign capital gave these companies the opportunity to amass capital and effect entry into industries previously denied to them. Finally, a third phase of discrimination disfavoured Chinese companies against those owned by "indigenous peoples".

Regulatory distortion is not however the only factor which is crucial in the creation of Type 2 network firms. So, too, is lack of technological specialisation and knowledge. Speaking of an early period (Yoshihara 1988, p. 44) says "Even in trading, it was difficult for the Chinese to deal in technical goods, because it required engineering knowledge (in order to offer a repair service)." The essence of the Type 2 network is that it exists to engage in artibrage, rather than investment.

Evidence for the philosophy underlying undifferentiated networks is provided by (Cragg 1996). "However, the Western preoccupation with pigeonholing is reviled. To the Chinese, each man is a universalist who will use his common sense and the talents of those around him to do any job not just to the best of his ability but to the heights of possibility" (p. 10).

Membership of the network may be a guide to the probability of transparency and openness. How far are foreigners/non-ethnic group members/foreign firms permitted entry?

The negative aspects of networks, in terms of their contribution to development, centres on the small contribution of networks to technology development, to the innovative aspects of marketing and to financial innovation. The first issue is demonstrated by the low (often zero) investment in research and development, the second by the limited creation of brands in networks and the third by the predominance of the circulation of liquid assets rather than the transfer of funds to productive sources and to fixed investment. Again, this may be a response to high levels of risk-stories of ethnic Chinese businessmen with suitcases fully of money, precious stones and gold, ready to move at a moment's notice abound [see for example, (Haley et al. 1998)]. Consequently, many Asian networks are over diversified as a response to uncertainty. Capital is not concentrated in a single activity and efforts to reduce diversification are met with resistance-e.g., recent attempts to provide more focus to Korean chaebols.

In addition, because of the inward looking nature of closed, opaque networks, there is little diffusion of best practice outside the network. Migration into and out of the network is limited, outsiders cannot copy any innovations made and network members attempt to retain rent rather than spread their innovations. Rent seeking through political influence, collusion and 'croneyism' are features of mature networks which exacerbate the non-innovative and non-diffusion elements of established networks. The interests of the insider clique militate against endogenous growth processes.

The cost of maintaining the network remains to be considered. Risk aversion (diversification) comes at a price. Liquidity comes at a price. That price is a reduction in the division of labour. Specialisation is inhibited and thus a major dynamic of growth-enhancement of the division of labour is not furthered. The opportunity cost of liquidity and diversification is investment in growth enhancing specialised research and development. Endogenous growth processes do not take root in economies based on Type 2 networks. 
Table 2 illustrates that not all "Asian network firms" are the same. Taking five dimensions-factor ownership, products, finance, market and source of technology, typical Keiretsu, Chaebol and Overseas Chinese companies are radically different types of network. Any analysis of international corporate networks must eschew 'one size fits all' modelling.

\section{Approach 4: Domestic Institutions}

The impact of domestic institutions on outward FDI has been explored most comprehensively in the case of China. The internationalization of Chinese companies is not only triggered by their aspiration to internalize imperfect markets across borders, but it is also influenced by the domestic institutional framework (Voss et al. 2009). Institutions in the form of the judiciary and bureaucracy, government structures, and other market mechanism enablers determine the playing field for companies and their incentive and reward systems by accidentally or intentionally creating market imperfections (North 1990). The influence of the institutional framework is not restricted to the domestic realm but can also play a crucial role (both positively and negatively) in the internationalization of domestic companies (cf. Boisot and Meyer 2008). Examples of direct institutional intervention include domestic market protectionism enforced by local political entities to protect (and nurture) local companies, uneven industrial policy, and restrictive and promotional home country measures concerning OFDI (Buckley et al. 2008). Developing countries typically have, by and large, a restrictive institutional environment towards OFDI in order to minimize the outflow of capital, because this is often perceived to ensure sound growth and to keep up with international developments in their specific industry.

In China, the" $[\ldots]$ state is constituted to act [...] as an active player, promoting and controlling economic development" (Scott 2002, p. 65). It managed a restrictive and cautious regulatory OFDI framework during the 1980s and 1990s (Zhan 1995). However, this changed with the liberalization efforts of the "Go Global" policy at the end of the 1990s. This key policy shift points to the need for better understanding of how the evolving institutional environment in China is moderating the internationalization strategies of domestic firms (Child and Rodrigues 2005).

Changes to China's institutional environment concerning OFDI are analysed using an institutional theory perspective. According to (North 1990) institutions define the formal and informal rules that constrain or drive economic interactions and growth within an economy and between economies. Institutional theory offers considerable explanatory power in international business research because the external institutional environment in which a firm operates, together with its internal resources and capabilities, shape to a considerable degree its competitiveness (Oliver 1997). This is especially the case in transition economy contexts where institutional change is often a defining characteristic. Institutions impinge on firms through the creation of market imperfections and through regulatory and social pressure. These two dimensions are discussed in more detail below starting with a static view and, thereafter, through the introduction of a dynamic dimension, which, 
Table 2 Diversity of Asian network firms Source: Buckley (2004), p. 269

\begin{tabular}{llll}
\hline & Keiretsu & Chaebol & $\begin{array}{c}\text { Overseas } \\
\text { Chinese }\end{array}$ \\
\hline $\begin{array}{l}\text { Factor } \\
\text { ownership } \\
\text { Products }\end{array}$ & Cross-shareholdings & Family (often disguised) & Family \\
Finance & Ingroup bank & Diversified & Diversified \\
Market & $\begin{array}{l}\text { Protected home market and } \\
\text { global sales }\end{array}$ & $\begin{array}{c}\text { Protected home market }+ \\
\text { international expansion }\end{array}$ & $\begin{array}{c}\text { Family 'Soft } \\
\text { Money' }\end{array}$ \\
Technology & $\begin{array}{c}\text { Licensed-in } \\
\text { Group development (incremental) }\end{array}$ & $\begin{array}{c}\text { Regional/local } \\
\text { Borrowed/low- } \\
\text { tech }\end{array}$ \\
\hline
\end{tabular}

we argue, is essential for an analysis of China given the extent of market reforms since the 1980 s.

Theory asserts that firms create competitive advantages for their domestic market by internalising and exploiting market imperfections which help them to create unique and difficult to replicate resources (Oliver 1997; Hymer 1960; Kindleberger 1969). Likewise, to invest internationally, firms must be capable of internalising and exploiting market imperfections across borders (Buckley and Casson 1976). This includes the ability to take advantage of market imperfections in the host market and the ability, through the exploitation of domestic imperfections, to create and sustain international competitiveness. The latter requires that domestically-acquired competitiveness is internationally transferable within the company without friction. Such market imperfections can be created through government actions and intervention (North 1990; Brewer 1993). Examples include the support that governments can give to selected firms in the form of special access to human and financial resources and directives that influence investment decisions. Differences in the transaction costs associated with accessing such government activities can create an artificial heterogeneity among companies within industries (Oliver 1997) and between different governance models of companies which is incongruent with the internal resources of the firms in question. With regard to outward investment this means that some domestic firms may benefit from (intentional or unintentional) government induced market imperfections which support their internationalisation strategy.

Pressure to comply with regulatory and social expectations, on the other hand, can undermine the competitiveness of a firm. Social expectation refers to a 'doing as usual' strategy that is socially and politically acceptable (Oliver 1997). Sub-optimal business and other social relationships are nurtured and maintained by both parties because of the social equity invested in them in the past and the danger of sunk costs. Organisations that are 'trapped' in such a situation may neglect alternative relationships and business practices because of uncertainty about how they may develop and lose established linkages. Acceptable firm behaviour is evident in investment decisions undertaken by a firm that reflects the expectations that political 
structures and society have of the firm concerning, for example, its size, status or business scope. But such investments do not necessarily have to correspond with a long-term sustainable business development plan. Regulatory pressure can lead to greater homogeneity among firms of a particular industry by imposing the same standards and requirements across all firms (e.g., through corporatisation and public listing) (Oliver 1997). This can undermine the search for uniqueness as a way to achieve and sustain competitiveness. In such circumstances, the internationalisation of firms may be at least partly driven by the perceived need to comply with regulatory, political and social expectations rather than be under-pinned by a coherent and realistic business rational. Government incentives may 'sweeten' compliance.

These static approaches provide an important background for the development of a dynamic perspective to understanding the interplay between institutions and businesses. In times of institutional transition (which can be defined as "fundamental and comprehensive changes introduced to the formal and informal rules of the game that affect organizations as players", see Peng 2003, p. 275), existing market imperfections will be substituted by new ones and the configuration of regulatory and social pressure will change. As we have seen, China, for example, has moved from a planned and autarkic economy towards an open, internationally integrated and more market-based economy since the 1980s. As part of this process, its institutional environment has also evolved, shifting from a relation-based governance system towards a more rules-based one ( $\mathrm{Li}$ et al. 2004; Peng 2003). In a relation-based governance system well established connections with influential parties (i.e., government officials) can often help to secure preferential treatment in general and, in particular, access to scarce resources (Li et al. 2004). Often, firms will tend to be locked-into such relationships as they bring benefits to all parties involved. Breaking up such a network would therefore create immense sunk costs for the firm and, to a lesser extent, to government officials. For outsiders, such a relationship represents an entry barrier because they do not receive equal treatment and cannot rely on publicly available information ( $\mathrm{Li}$ et al. 2004). A rules-based governance system is characterised by objective and transparent decision-mechanisms and procedures.

Though institutional change happens, it usually does not occur homogeneously. (Krug and Hendrischke 2008) argue, for example, that China is today characterised by three different types of economic regime that are emerging at a local level which can be described as 'arm's length', 'developmental state', and 'pre-corporatist'. These regimes have evolved during the process of institutional transition because of different institutional innovations and incremental change that has taken place at different rates across regions of China depending on the location-bound mediation and negotiation of local businesses and local government officials. These (subnational) regimes support businesses differently, attract different types of businesses and can cause agglomerations of business activity (Krug and Hendrischke 2008). Therefore, such sub-national variation is likely to affect outward investment uniquely (Voss et al. 2009).

The impact of domestic institutions on OFDI has not been so thoroughly investigated outside of China. The 'push' factor is generally expressed as a desire to 
escape restrictive domestic institutions (laws and regulations, institutional corruption, political control) and a slow growing domestic market. Volatility at home, often arising from political instability can often lead firms to seek safer havens. This can elide into capital flight where OFDI is simply a cover for the export of capital, often into safe assets, such as property. Capital flight is difficult to distinguish from conventional OFDI in statistical treatments of FDI. In capital flight companies are used as cover for the international transfer of personal wealth internationally.

\section{Cases}

The paper now goes on to apply the four research approaches to three casesChinese OFDI, Indian foreign acquisitions and EMNEs' investments in tax havens. The analysis of the cases follows the structure of the four research approaches and highlights the role of internalisation theory in each, as it applies to the particular case. $^{2}$

\subsection{Case 1: Chinese Outward Foreign Direct Investment}

Outward Foreign Direct Investment (OFDI) by emerging country MNEs (EMNE) is not a single phenomenon. This is particularly true in the case of China as an analysis of Chinese OFDI shows.

\subsubsection{Management of Chinese MNEs}

Table 3 shows that there are a wide variety of "emerging market MNEs". In the case of China, State Owned Enterprises (SOEs) are often seen as the national champions. Because rates of return in the domestic Chinese economy are low in the traditional sectors in which these SOEs operate (including steel, cement and aluminium), largely because of overcapacity and a reluctance to rationalise these industries on account of the adverse employment impact, there is a tendency to see foreign markets as an outlet. (This leads to accusations of "dumping"—selling below cost). In addition, top management appointments are the purview of the State (Party) and top executives are often shifted between industries, leading to myopic decision making and lack of real industry expertise at the top level. China also has a small (but very slow growing) number of world stage aspirants and few global niche players (the latter because this requires nimble innovation and market knowledge). What China does have is a non-state owned sector containing a number of internationally orientated firms with deep pockets that acquire foreign technology in order to bring that technology back to the Chinese market. These "domestic market focused acquirers" should not be mistaken for truly global companies-they are purely China market focussed for the foreseeable future. Finally, entrepreneurial and family businesses include migrating entrepreneurs (e.g., chicken farmers in

\footnotetext{
${ }^{2}$ The numbering of the subheadings in the cases refers to the four research approaches above.
} 
Table 3 Organisational form and ownership of EMNEs

\begin{tabular}{lll}
\hline & Ownership & \\
\cline { 2 - 3 } & State owned & Private \\
\hline Organizational form & & \\
Corporate investor & State-owned corporations & Non-state owned corporations \\
& National champions & World-stage aspirants \\
& & Global niche players \\
& & Private equity funds \\
Entrepreneurial investor & Entrepreneurial and family businesses \\
& & Entrepreneurial cluster participants \\
& & International entrepreneurs \\
\hline
\end{tabular}

Africa) and small firms that form foreign cluster investors, centred on focal Chinese foreign investors or even foreign business parks.

The lesson of this section is that Chinese OFDI is not a single phenomenon-the peculiar imperfections of the Chinese market and its institutional make up, including the pervasiveness of State/Party actors render a careful "institutional" model essential for understanding of the complexity of Chinese "multinationals".

\subsubsection{Domestic Capital Market Imperfections}

It is a well known macroeconomic nostrum that it is not possible to combine (a) control of domestic monetary policy (through interest rates), (b) fix interest rates and have (c) free flows of capital internationally. China has attempted to control (a) and (b) whilst liberalising - in step changes - (c) free flows of capital. In practice this has involved an awkward ongoing set of compromises. The renminbi has been allowed to appreciate in jumps whilst capital outflows have been allowed over a wider range of transactions. For OFDI, this has meant a staged liberalisation. The imperfections however in the domestic capital market-easier access to funds for SOEs than private sector companies (unless specially favoured for political or strategic reasons) combined with this jerky dynamic compromise over policy goals have led to some idiosyncratic OFDI outflows in terms of sector and location (Buckley et al. 2007).

Care is necessary in interpreting COFDI figures both on a cross section and a time series basis. Theory has to be applied with caution because of the political, institutional and cultural influences. This also applies to network relationships in China.

\subsubsection{International Networks}

6.1.3.1 Phalanx Foreign Direct Investment "China's companies should combine their efforts in 'going out'. They should share experiences and form industry chains 
in foreign countries. Liu Yonghao, Chairman of the Sichuan-based New Hope Group (Quoted in China Daily, European Weekly, 24-30 April 2015, p. 18).

One major unresolved, issue is the extent of State direction of Chinese MNEs. It is possible to envisage Chinese SOEs investing as a phalanx. Managers of Chinese SOEs are not sophisticated in FDI decision making and so are guided by State institutions-including financial institutions like the Chinese Investment Corporation (CIC). The coordinated nature of Chinese OFDI and the state-directed element is different from conventional capitalist FDI but the extent of this difference is mitigated by (1) normal exchange of information among companies and (2) the long remarked 'bandwaggon' and 'follow my leader' processes (Knickerbocker 1973). In addition (3) value chain leadership requires coordination (Buckley 2004, 2007, 2009a, b, 2010, 2011a, b, 2012).

6.1.3.2 Lishu relationships in China Lishu is a Chinese word that conveys the meaning of "belonging to", "subordinate to" or "directly controlled by" (Du 2015). With such a relationship between governments (Central, Provincial even local [township, county, prefecture residents' and villagers' committees)] and firms- the government body has administrative power to control firm structures, directors, senior managerial appointments, business plans, major projects and even operational decisions. The Chinese National Bureau of Statistics (NBS) codes enterprises according to their government affiliation ( Du 2015).

6.1.3.3 'Going Out' Strategy It is a mistake to assume that all Chinese firms are in receipt of government aid and support to go abroad. (Voss et al. 2010) provide interview based evidence that smaller and private companies and even some SOEs are discouraged from investing abroad, slowed by regulations and discretely 'persuaded' not to invest abroad. The 'going out' strategy is not uniform and is discriminatory.

The argument that in an authoritarian state 'politics trumps economics' does not however seem to be the case with an overall explanation of Chinese OFDI. Government does interfere but this interference is differential-across ownership groups (SOEs and private companies may be both encouraged/subsidised and impeded/discouraged), sectors, Provinces and types of firm. There is anecdotal evidence of dumping (e.g., of steel) on foreign markets-and this is a substitute policy for painful domestic restructuring.

\subsubsection{Domestic Institutions and Capital Flight}

The points on macroeconomic policy above in relation to exchange rate policy are pertinent to the potential capital flight element in capital outflows from China. The use of private companies to export capital (notably through Hong Kong) are difficult to document and the capital flight element of Chinese OFDI is difficult to estimate-it is however, non-trivial.

Capital flight is difficult to separate from the other motives in foreign investment, and permeates all types of international flow. It is reported that Chinese investors 
placed $£ 3$ million in London property in 2015 and are likely to increase that figure in 2016 [Times 01.02.16 quoting CBRE (the world's biggest property group) data]. Investment in secure foreign property is a key hedge instrument in foreign capital flight.

The issue of capital flight, in China as everywhere, is bound up with the value of the currency. The management of the Renminbi is thus critical. The collapse of the values on the Chinese stock exchanges (July-August 2015) triggered an outflow of capital, illustrating the links between (the strength of) domestic institutions and external investment. China's capital controls also influence outward flows. These controls extend to foreign owned firms in China-only "qualified foreign institutional investor" status confers the right to trade in Chinese equities and even thus is quantity-limited. The encouragement of a wider range of foreign investors would reduce capital flight as would a range of financial reforms in China (Dakers 2016). Liberalisation of the domestic financial market to both local and foreign institutions would remove some of the incentives for capital flight.

6.1.4.1 Summary: Chinese OFDI Chinese OFDI clearly requires careful, contextually based and nuanced explanations because it is not one uniform phenomenon. It has also been argued that off-the-shelf explanations of OFDI from emerging countries does not simply fit China. Table 4 exemplifies these arguments and shows that a "standard model" of emerging country FDI derived from a number of theoretical standpoints simply does not fit the Chinese case. Firm specific advantages cannot simply be assumed, Chinese OFDI does not follow the predictions of the Uppsala or stages model, nor does it "learn" first from weaker less competitive markets in emerging countries before going to "tougher" advanced country markets. IJVs are not the preferred means of going abroad and host government support is important but not overwhelmingly so because of private and entrepreneurial companies, some of which are actually disadvantaged by government favouritism (Buckley et al. 2008).

In consequence an internalisation theory explanation of Chinese OFDI is by far the most satisfying approach, because it allows for the explanation of the different components of Chinese OFDI, eschews a 'one size fits all' explanation and enables real analytical precision.

\subsection{Case 2: Indian Foreign Acquisitions}

Indian outward FDI is dominated by acquisitions, particularly in advanced countries.

\subsubsection{International Acquisition Strategies: Acquiring Strategic Assets}

Indian firms have built a reputation by acquiring advanced country firms. Explanations can be sought in internalisation theory by examining (again) the domestic capital market and English language usage-reducing the costs of operating international internal markets, reducing the liability of foreignness and fostering 
Table 4 Chinese OFDI and standard theoretical explanations of emerging country OFDI Source: derived from Buckley et al. (2008)

\begin{tabular}{|c|c|c|}
\hline & Theoretical explanation & Chinese OFDI \\
\hline 1 & $\begin{array}{l}\text { Firm specific advantages of firms ("have country } \\
\text { embeddedness") }\end{array}$ & $\begin{array}{l}\text { Partially, Yes-some Chinese firms enjoy access } \\
\text { to cheap capital }\end{array}$ \\
\hline 2 & Early OFDI occurs in other developing countries & $\begin{array}{l}\text { No-early Chinese OFDI was directed mostly to } \\
\text { developed countries }\end{array}$ \\
\hline 3 & $\begin{array}{l}\text { OFDI occurs in culturally and geographically } \\
\text { close countries (Uppsala model) }\end{array}$ & $\begin{array}{l}\text { No-early Chinese OFDI was directed to } \\
\text { physically and geographically distant countries }\end{array}$ \\
\hline 4 & $\begin{array}{l}\text { Later OFDI occurs in more advanced countries } \\
\text { ("stages theory") }\end{array}$ & $\begin{array}{l}\text { No-both early and later OFDI occurs in } \\
\text { advanced economies }\end{array}$ \\
\hline 5 & $\begin{array}{l}\text { International joint ventures (IJVs) are the main } \\
\text { entry mode-particularly in early OFDI }\end{array}$ & $\begin{array}{l}\text { No-both IJV and wholly owned affiliates are } \\
\text { utilised }\end{array}$ \\
\hline 6 & Home government support important & Yes-but nuanced by type of firm (see Table 3 ) \\
\hline
\end{tabular}

links through shared institutions. External and conventional explanations such as the exchange rate and firm strategies are also important.

\subsubsection{India: Domestic capital market}

The home stock market can be an important source of finance. Stock market valuations were found to have significant explanatory power for U.S. investments abroad (Barrow 1990) as MNEs make extensive use of their internal capital market to finance FDI projects (Herzer 2008). (Baker et al. 2009) found that FDI flows are strongly related to the home country's stock market valuation, as high stock valuations at home make financing cheaper by reducing the cost of capital. The association between stock market valuations and FDI is a strong one. As Baker et al. puts it, "the effect of source country valuations is stronger, in statistical terms, than any other determinant of FDI that we study, and to our knowledge may be the strongest effect on FDI yet documented in the literature. This relationship is consistent with the cheap finance story" (Baker et al. 2009, p. 22).

India's capital market remained buoyant especially during the period 2003-2007 with significant inflows of global portfolio investments. A high capital market index indicates high stock prices and a low cost of capital. Thus, rising stock prices in the domestic capital market may have enabled firms to raise equity from both primary and secondary markets cheaply. Interestingly, Indian firms have raised record-high amounts of capital during the period under study which also coincides with increasing levels of cross border acquisitions by Indian MNEs. Thus, it is likely that the rising home capital market index has enabled Indian firms to finance overseas acquisitions. 


\subsubsection{The Use of International Networks to Reduce Transaction Costs}

6.2.3.1 Business Groups Business Groups may be defined as "clusters of independent companies, linked together, or to a major holding, by significant shareholding enough to exert some control on the strategic behaviour of the companies themselves" (Colli and Vasta 2015, p. 7). Business groups enhance the control of dominant shareholders as a limited amount of input of their own resources can ensure widespread leverage. The subsidiaries within business groups may also be given freedom and incentives to pursue "independent" strategies not possible within a more strict, possibly divisionalised, organisational structure. Family control can be combined with fiscal autonomy of the enterprises within the group, shareholder (non-family) pressure diffused and non-related diversification strategies pursued.

In the case of India a business group or enterprise group is usually a diversified enterprise owned and managed by a family. Business groups can be seen as a pool of resources which can promote the internationalisation of the affiliated firms (Yiu et al. 2005). In principle business groups provide an internal financial market to channel capital to those parts of the group able to marshal the resources to acquire abroad. They can also transfer other resources needed to expand abroad internally, such as knowledge. The literature suggests that firms may internationalise by leveraging group resources (Douma et al. 2006; Guillén 2003; Tan and Meyer 2010; Yiu et al. 2005). Besides accessing the internal pool of resources, synergy between different subsidiaries of an Indian business group can also facilitate internationalisation of the firm; for instance, synergies between the subsidiaries of Tata group (Mukherjee and Radhakrishnan 2002). Business groups are dominant in many emerging economies (Tan and Meyer 2010; Khanna and Palepu 1999; Peng and Heath 1996). Most Indian business groups are diversified across several industries and are highly internationalised at the same time; for instance, Tata group operates in 28 industries and has a presence in about 80 countries (Tata 2012).

6.2.3.2 English Language A common language facilitates business by improving communication and bridging cultural and psychic distance (Bond and Yang 1982; Doh et al. 2009). Recently, language has been found to be an important driver of foreign direct investment (Akkermans et al. 2010; Doh et al. 2009; Feely and Harzing 2002) as it can reduce transaction costs (Buckley and Casson 1976; Williamson 1981) and facilitate business exchange (Doh et al. 2009). We argue that proficiency in the English language by Indian youth is also a CSA on which many Indian firms can draw to create strong internal labour markets. This has enabled many Indian firms to become leading business services providers in the world, e.g., Infosys, Tata Consultancy Services (TCS).

The English language is a legacy of Britain's colonial rule. During that era many Indian leaders such as Pt. J. L. Nehru, India's first prime minister, Mahatma Gandhi and many others were educated in British universities and on India's obtaining independence in 1947, they adopted the English language as second official language in India along with British systems of governance. Today India has the 
largest number of English-speaking people in the world and the largest-selling English daily newspaper, the Times of India. The ability of Indians to converse in English language enhances the ability of Indian business houses to internationalise especially in English-speaking countries. Thus, we anticipate that Indian firms would be more inclined to do business with the English speaking countries.

6.2.3.3 India: Foreign exchange rate Our second argument is that the exchange rate of the Indian rupee against the U.S. dollar has facilitated the undertaking of foreign direct investments by Indian firms. An appreciation of the home country currency discourages exports while encouraging overseas investment, therefore facilitating import-substituting FDI. Many studies (Aliber 1970; Blonigen 1977; Stevens 1993) centre on the exchange rate as a critical determinant of FDI.

The strengthening of the Indian rupee against the U.S. dollar during the period 2003-2007, which made the valuation of target companies abroad attractive, coincided with a surge in foreign acquisitions by Indian firms. The exchange rate of the Indian rupee against the U.S. dollar, which peaked in 2002 at 48.6 INR/USD appreciated by more than $15 \%$ by 2007 . This might have had an impact on the volume of foreign acquisitions.

\subsubsection{Domestic Institutions: Multi-State Experience in India}

India is a multi-state, multi-religion, multi-language, multicultural country. Companies that operate across India experience many of the issues that are first raised for monocultural countries when they internationalise. Thus large Indian companies have faced many of the hazards of internationalising before they leave India. Indian domestic companies also face different tax regimes in the different states of India-hence the difficulties of standardising on the Goods and Services Tax (GST), currently proposed (2016) but proving difficult (politically) to implement.

It can therefore be argued that operating across India is excellent preparation for internationalisation.

6.2.4.1 Summary: Indian Foreign Acquisitions Indian foreign acquisitions are explained by the need of India MNEs to internalise technology, skills and marketrelated information, and to acquire brands. Domestic conditions favour the accumulation of capital through a buoyant stock market and business network cross subsidy to finance these acquisitions. The domestic institutions of a multi ethnic, multi language, multi religious, multicultural state allow Indian MNEs to learn to work across boundaries and the widespread use of English is a transaction cost reducing bonus. 


\subsection{Case 3: EMNEs and Tax Havens}

\subsubsection{Tax Havens and Offshore Financial Centres}

\subsubsection{International Investment Strategy: Capital Augmenting and Tax Reduction} Strategies EMNEs have a high penchant for investing in tax havens and offshore financial centres (THOFCs), notably China. This penchant is also explained by internalisation theory in combination with an understanding of the above four approaches-international strategy, domestic capital market imperfections, international networks and domestic institutions (for full details see Buckley et al. 2014a, b).

Despite the interest of economic geographers in both financial centres and the role of capital market imperfections in determining economic geography, there remains a dearth of firm-level analysis explaining offshore incorporation in THOFCs. Following from this, there are a number of reasons why the location choice of FDI as explained by internalisation theory (Buckley and Casson 1976; McCann 2011), provides a complementary approach to the financial geography literature looking at THOFCs. First, internalisation theory, which is based upon transaction cost economics and the theory of the firm, provides an explicit microlevel perspective with which to analyse offshore incorporation and the related FDI to THOFCs. As noted, financial geography has paid less attention to how firm-level financing decisions impact upon firm-level corporate economic geographies. Rather, its interest has been directed more towards the geography of financial supply architectures and systems (Wrigley 1999). Secondly, financial geography grew, in part, from the recognition that imperfect capital markets shape economic geographies. Internalisation theory specifically deals with the role imperfect markets, including the impact of imperfect capital markets on FDI (Buckley and Casson 2009), lending itself to cross-fertilisation with financial geography.

6.3.1.2 Domestic Capital Market Imperfections Emerging markets, as noted, are renowned not only for their domestic capital market imperfections but also for their relatively poor domestic institutional environments and the high transactions costs that these can create (Khanna and Yafeh 2007). Emerging market businesses are often forced to undertake a wide variety of innovative responses in an attempt to mitigate these high transactions costs. A considerable literature, for example, explains the formation of 'business groups' as preferred organisational forms in emerging markets as one such response mechanism (Khanna and Yafeh 2007) summarise this extensive literature). The most successful THOFCs, by contrast, are recognised for their well-developed legal and financial systems, particularly those havens that also act as offshore financial centres (OFCs) (Dharmapala and Hines 2009; Rose and Spiegel 2007; Roberts 1995). The drive for offshore incorporation and FDI flows may, therefore, be driven not only by domestic capital market imperfections and the needs of EMNEs to augment their existing capital structure, but also by access to a more favourable institutional environment. 
Internalisation theory accounts for the impact of imperfect markets and also draws attention to these broader institutional misalignments, including how businesses exploit multi-country presence (Dicken 2003). These may drive what has been referred to as 'institutional arbitrage' (Boisot and Meyer 2008; Kedia and Mukherjee 2009), in which EMNEs use THOFCs to internalise institutional and market differences between countries, with the strategic intent of guaranteeing their long term economic viability. As such, firm-level financing and institutional arbitrage decisions may become an important determinant of where MNEs invest.

The search for tax reducing devices and investment in offshore financial centres is a good fit with the argument of (Witt and Lewin 2007) that OFDI by EMNEs is an 'escape response' to home country institutional constraints-particularly with regard to domestic financial conditions. These financial conditions may restrict payments to executives, or tax corporate and personal incomes at punitively high levels.

\subsubsection{Geographical, Social and Financial International Network Links Eco-} nomic geographers have seen MNEs as geographical constellations of social relationships (Dicken 2003; Yeung 2009) that invest along horizontal and vertical axes (Shatz and Venables 2003). In addition, they have at times decried what they see as the 'methodological nationalism' of some IB scholars, in so far as they too closely follow the precepts of neoclassical economics [as exemplified by (Yeung 2009)]. Neoclassical economic theories and IB variants that build on them, for example, assume free and costless movement of capital and labour and perfect and ubiquitous information flows. It is argued these theories, including internalisation theory, do not therefore explicitly address the role of territory in the case of financial flows and systems, or the spatially embedded nature of MNEs (Martin 1999; Yeung 2009; Seo 2011). We look to address these criticisms here by arguing that localities and their specificities do matter, are location bound and are very difficult to transfer. As such, we regard the MNE as a locally embedded network of relationships, focussing here on financial relationships in particular. By doing so the article progresses our understanding of the globalisation of EMNEs and their corporate financial geographies (Coe and Yeung 2001). It also advances the theory of the MNE by focussing on the wider institutional framework of the global economy and relaxing the assumption that MNE's 'decision making and corporate behaviour are the same everywhere' (Yeung 2009). Geography is therefore conceptualised as a central component of the existence of MNEs (Beugelsdijk et al. 2010).

\subsubsection{Domestic Financial Institutions It is the contrast between domestic} financial institutions and those of the offshore financial centres that is crucial in explaining outward FDI from emerging market countries to these centres. The relative inability of EMNEs to use domestic financial institutions to help in internationalising is (in addition to the reduction of taxation) a key motive. Access to foreign, particular US, capital markets through offshore financial centres enables capital augmentation and potentially listing on the New York Stock Exchange. 
The issue of 'capital flight' has become serious for China as high net worth individuals seek to place their savings in safe assets outside China, partly at least, due to the financial repression reported above. This affects both portfolio and direct foreign investment and has led to a tightening of capital controls on Renminbi outflows (Subacchi 2017). The privatisation of state owned assetssometimes orchestrated through offshore financial centres (Pei 2016) results in capital flight being designated as "foreign direct investment". International flows to take advantage of tax arbitrage also are "disguised" as OFDI. The attempt to disentangle 'real' from 'financial' flows will always bedevil studies of FDI-and in the Chinese case, substantiating these elements is difficult-and dangerous!

This issue illustrates the influence of the exchange rate on OFDI. An undervalued exchange rate stimulates exports and discourages OFDI. This was the case with China when it was basing growth on export orientation (which similarly implies domestic financial repression). As the Renminbi was allowed to appreciate, the repressed outward financial flows were exported in various forms-including OFDI. China now has the ambition that the Renminbi should become one pole of the world financial system-to become part of the 'basket' of reserve currencies (not necessarily the top currency) and this implies equilibrating the exchange rate with world financial flows (Subacchi 2017). This 'managed convertibility' will encourage outflows-including 'real' OFDI and financial flight capital-sadly (for analysts) often inextricably mixed.

\subsubsection{Summary: EMNEs and Tax Havens}

A large share of the outward foreign direct investment (FDI) of emerging market MNEs is directed towards a small number of specific tax havens and offshore financial centres. The establishment of investment-holding companies for taxation related purposes is frequently adduced as a key motivation ('round-tripping') for these investments. This explanation, however, accounts for neither the concentration of such investments in specific havens nor the comparatively large national shares of such investments that originate from emerging markets.

In particular, the extent and ways in which firm-level financing decisions specifically influence the location decisions of MNEs have been somewhat overlooked. This omission is surprising, given it is well known that large volumes of FDI pass through THOFCs and that significant MNE activity is undertaken offshore, including the raising of capital and property rights transactions. This type of FDI, however, is often not considered to be involved in physically 'productive activity' (Beugelsdijk et al. 2010). It also does not easily fit under the categories of market, efficiency or asset seeking investment motivations or horizontal and vertical investments (Shatz and Venables 2003), that the international business literature often focuses upon. As a result, it is often dismissed. 


\section{Conclusion}

This paper has described four generic research approaches to the internationalisation of emerging market multinational enterprises: international investment strategy, domestic market imperfections, international networks and domestic institutions. It then applied each of these four approaches to three salient cases-Chinese outward foreign direct investment, Indian foreign acquisitions and investment by EMNEs in tax havens. Internalisation theory plays a crucial role in all four research approaches and in the analysis of all three cases. It is important that the analysis of OFDI from emerging market multinationals is analysed within an overarching theoretical rubric. The alternative is fragmentation, the accumulation of unrelated special cases, and theoretical confusion. The use of internalisation theory is to be commended not only because of theoretical inclusivity, but also for its ability to connect, and to explain, seemingly disparate phenomena.

Acknowledgements Earlier versions of this paper were given at the European International Business Academy (EIBA) in Rio de Janeiro, December 2015, at the University of Gothenburg Business School and Copenhagen Business School (June 2016) and at the "China Goes Global" Conference in Macerata, Italy (July 2016). Participants are thanked for their constructive comments. I would like to thank the editors and referees of MIR for their insightful comments.

Open Access This article is distributed under the terms of the Creative Commons Attribution 4.0 International License (http://creativecommons.org/licenses/by/4.0/), which permits unrestricted use, distribution, and reproduction in any medium, provided you give appropriate credit to the original author(s) and the source, provide a link to the Creative Commons license, and indicate if changes were made.

\section{References}

Aharoni, Y. (1966). The foreign investment decision process. Cambridge: Harvard Business School Press.

Akkermans, D., Harzing, A. W., \& van Witteloostuijn, A. (2010). Cultural accommodation and language priming: Competitive versus cooperative behavior in a prisoner's dilemma game. Management International Review, 50(5), 559-584.

Aliber, R. Z. (1970). A theory of direct foreign investment. In C. Kindleberger (Ed.), The international corporation: A symposium (pp. 17-34). Cambridge: MIT Press.

Aliber, R. Z. (1971). The multinational enterprise in a multicurrency world. In J. H. Dunning (Ed.), The multinational enterprise. London: George Allan \& Unwin.

Baker, M., Foley, C. F., \& Wurgler, J. (2009). Multinationals as arbitrageurs: The effect of stock market valuations on FDI. The Review of Financial Services, 22(1), 337-369.

Barney, J. B. (1986). Strategic factor markets: expectations, luck and business strategy. Management Science, 32(10), 1231-1241.

Barrow, R. J. (1990). The stock market and investment. The Review of Financial Studies, 3(1), 115-131.

Beugelsdijk, S., McCann, P., \& Mudambi, R. (2010). Introduction: place, space and organizationeconomic geography and the multinational enterprise. Journal of Economic Geography, 10(4), 485-493.

Blonigen, B. A. (1977). Firm-specific assets and the link between exchange rates and foreign direct investment. The American Economic Review, 87(3), 447-465.

Boisot, M., \& Meyer, M. W. (2008). Which way through the open door? Reflections on the internationalization of chinese firms. Management and Organization Review, 4(3), 349-365. 
Bond, M. H., \& Yang, K. S. (1982). Ethinic affirmation versus cross cultural accommodation: The variable impact of questionnaire language on Chinese bilinguals from Hong Kong. Journal of CrossCultural Psychology, 13(2), 169-185.

Brewer, T. L. (1993). Government policies, market imperfections and foreign direct investment. Journal of International Business Studies, 24(1), 101-120.

Buckley, P. J. (2004). Asian network firms: An analytical framework. Asia Pacific Business Review, 10(3/ 4), 254-271.

Buckley, P. J. (2007). The strategy of multinational enterprises in the light of the rise of China. Scandinavian Journal of Management, 2(2), 107-126.

Buckley, P. J. (2009a). The impact of the global factory on economic development. Journal of World Business, 44(2), 131-143.

Buckley, P. J. (2009b). Internalisation thinking - from the multinational enterprise to the global factory. International Business Review, 18(3), 224-235.

Buckley, P. J. (2010). The role of headquarters in the global factory. In Ulf Andersson \& Ulf Holm (Eds.), Managing the contemporary multinational (pp. 60-84). Edward Elgar: Cheltenham.

Buckley, P. J. (2011a). Globalization and the global factory (p. 634). Cheltenham: Edward Elgar.

Buckley, P. J. (2011b). International integration and coordination in the global factory. Management International Review, 51(2), 269-283.

Buckley, P. J. (2012). The multinational enterprise as a global factory. In Alain Verbeke \& Hemant Merchant (Eds.), Handbook of research on international strategic management (pp. 77-92). Cheltenham: Edward Elgar.

Buckley, P. J. (2014). Forty years of internalisation theory and the multinational enterprise. Multinational Business Review, 22(3), 227-245.

Buckley, P. J. (2016). The contribution of internalisation theory to international business: New realities and unanswered questions. Journal of World Business, 51(1), 74-82.

Buckley, P. J., \& Casson, M. (1976). The future of the multinational enterprise. London: Macmillan.

Buckley, P. J., \& Casson, M. (1988). A theory of cooperation in international business. In F. J. Contractor \& P. Lorange (Eds.), Cooperative strategies in international business. Lexington: Lexington Books, D. C. Heath \& Co.

Buckley, P. J., \& Casson, M. (2009). The internalisation theory of the multinational enterprise-a review of the progress of a research agenda after 30 years. Journal of International Business Studies, 40(9), $1563-1580$.

Buckley, P. J., Chen, L., Clegg, J., \& Voss, H. (2016). Experience and FDI risk-taking: A microfoundational reconceptualisation. Journal of International Management, 22(2), 131-146.

Buckley, P. J., Clegg, J., Cross, A., Zheng, P., Voss, H., \& Liu, X. (2007). The determinants of Chinese outward foreign direct investment. Journal of International Business Studies, 38(4), 499-518.

Buckley, P. J., Cross, A. R., Tan, H., Voss, H., \& Liu, X. (2008). Historic and emergent trends in chinese outward direct investment. Management International Review, 48(6), 715-748.

Buckley, P. J., Elia, S., \& Kafouros, M. (2010). Acquisitions from emerging countries: what factors influence the performance of target firms in advanced countries? European Journal of International Management, 4(1/2), 30-47.

Buckley, P. J., Elia, S., \& Kafouros, M. (2011). FDI from emerging to advanced countries: some insights on the acquisition strategies and on the performance of target firms. Economia e Politica Industriale (Journal of Industrial and Business Economics), 38(1), 181-197.

Buckley, P. J., Elia, S., \& Kafouros, M. (2014a). Acquisitions by emerging market multinationals: Implications for firm performance. Journal of World Business, 49(4), 611-632.

Buckley, P. J., \& Ghauri, P. N. (2004). Globalisation, economic geography and the strategy of multinational enterprises. Journal of International Business Studies, 35(2), 81-98.

Buckley, P.J., \& Hashai, N. (2004). A global system view of firm boundaries. Journal of International Business Studies 35(1), 33-45.

Buckley, P. J., \& Mirza, H. (1988). The strategy of pacific asian multinationals. Pacific Review, 1(1), 50-62. (Reprinted in Buckley, P.J. (1989). The multinational enterprise: theory and applications, London: Macmillan.).

Buckley, P. J., Sutherland, D., Voss, H., \& El-Gohari, A. (2014b). The economic geography of offshore incorporation in tax havens and offshore financial centres: The case of Chinese MNEs. Journal of Economic Geography., 14(6), 1-26.

Casson, M. (1979). Alternatives to the multinational enterprise. London: Macmillan. 
Casson, M. (1987). The firm and the market: Studies on multinational enterprise and the scope of the firm. Oxford: Basil Blackwell.

Casson, M. (1997). Information and organisation: A new perspective on the theory of the firm. Oxford: Clarendon Press.

Casson, M. (2000). Economics of international business: A new research agenda. Cheltenham: Edward Elgar.

Caves, R. E. (1980). Industrial organization, corporate strategy and structure. Journal of Economic Literature, 58, 64-92.

Central Intelligence Agency. (2017). The world factbook. Washington DC: Central Intelligence Agency.

Chen, H., \& Chen, T.-J. (1998). Network linkage and location choice in foreign direct investment. Journal of International Business Studies, 29(3), 445-467.

Child, J., \& Rodrigues, S. B. (2005). The internationalization of chinese firms: A case for theoretical extension? Management and Organization Review., 1(3), 381-410.

China Daily, European Weekly, 24-30 April 2015, p 18.

Coe, N. C., \& Yeung, H. W.-C. (2001). Geographical perspectives on mapping globalisation. Journal of Economic Geography, Special Issue, 1, 367-380.

Colli, C., \& Vasta, M. (2015). The enduring logic: The history of business groups in Italy (p. 723). No: Università di Siena Quaderni del Dipartimento di Economia Politica e Statistica.

Cragg, C. (1996). The new taipans. London: Arrow Books.

Cuervo-Cazurra, A., \& Ramamurti, R. (Eds.). (2014). Understanding multinationals from emerging markets. Cambridge UP: Cambridge.

Dakers, M. (2016). What Chinese stocks on benchmark indices would mean for passive investors. Sunday Telegraph Business News. 05.06.16 (pp 6-7).

Deng, P. (2004). Outward investment by Chinese MNCs: Motivations and implications. Business Horizons, 47(3), 8-16.

Deng, P. (2012). The internationalization of chinese firms: A critical review and future research. International Journal of Management Reviews, 14(4), 408-427.

Dharmapala, D., \& Hines, J. R., Jr. (2009). Which countries become tax havens? Journal of Public Economics, 93(9-10), 1058-1068.

Dicken, P. (2003). Global shift (4th ed.). London: Sage.

Doh, J. P., Bunyaratavej, K., \& Hahn, E. D. (2009). Separable but not equal: The location determinants of discrete services offshoring activities. Journal of International Business Studies, 40(6), 926-943.

Douma, S., George, R., \& Kabir, R. (2006). Foreign and domestic ownership, business groups, and firm performance: evidence from a large emerging market. Strategic Management Journal, 27(7), 637-657.

Du, J. (2015). Political connections and exporting decisions. Evidence from the perspective of Lishu relationship in Chinese unlisted firms: University of Birmingham, mimeo.

Dunning, J. H. (2000). The eclectic paradigm as an envelope for economic and business theories of the MNE. International Business Review, 9(2), 163-190.

Dunning, J. H., \& Lundan, S. M. (2008). Multinational enterprises and the global economy (2nd ed.). Cheltenham: Edward Elgar.

Eden, L., \& Dai, L. (2010). Rethinking the O in Dunning's OLI/Eclectic paradigm. Multinational Business Review, 18(2), 13-34.

Eriksson, T., Nummela, N., \& Saarenketo, S. (2014). Dynamic capability in a small global factory. International Business Review, 23(1), 169-180.

Feely, A.J., \& Harzing, A.W.K. (2002). Forgotten and neglected-language: The orphan of international business research. In Paper accepted for presentation at the 62nd annual meeting of the Academy of Management, Denver, August 9th-14th.

Gerschenkron, A. (1962). Economic backwordness in historical perspective. Cambridge: Belknap Press.

Godley, A. (2014). What does history add to EMNC research? In A. Cuervo-Cazurra \& R. Ramamurthi (Eds.), Understanding multinationals from emerging markets. Cambridge: Cambridge University Press.

Guillén, M. F. (2003). Experience, imitation, and the sequence of foreign entry: Wholly owned and jointventure manufacturing by South Korean firms and business groups in China, 1987-1995. Journal of International Business Studies, 34(2), 185-198.

Haley, G. T., Tan, C. T., \& Haley, U. C. V. (1998). New Asian Emperors: The overseas Chinese, their strategies and competitive advantages. Boston: Butterworth, Heinemann. 
Hennart, J.-F. (2009). Down with MNE-centric theories! Market entry and expansion as the bundling of MNE and local assets. Journal of International Business Studies, 40(9), 1432-1454.

Hennart, J.-F. (2012). Emerging market multinationals and the theory of the multinational enterprise. Global Strategy Journal, 2(3), 168-187.

Hennart, J.-F., Seng, H. S., \& Pimenta, G. (2014). Local complementary inputs as drivers of entry mode choices: The case of US Investments in Brazil. International Business Review, 24(3), 466-475.

Herzer, D. (2008). The long-run relationship between outward FDI and domestic output: Evidence from panel data. Economic Letters, 100(1), 146-149.

Hinterhuber, A. (2002). Value chain orchestration in action and the case of the global agrochemical industry. Long Range Planning, 35(6), 615-635.

Hitt, M. A., Lee, H., \& Yucel, E. (2002). The importance of social capital to the management of multinational enterprises: Relational networks among asian and western firms. Asia Pacific Journal of Management, 19(2), 353.

Hymer, S. A. (1960). The international operations of national firms: A study of direct foreign investment. Cambridge: MIT.

Jesudason, J. V. (1989). Ethnicity and the economy. Singapore: Oxford University Press.

Johanson, J., \& Vahlne, J. E. (1977). The internationalization process of the firm: A model of knowledge development and increasing foreign market commitments. Journal of International Business Studies, 8(1), 23-32.

Johanson, J., \& Vahlne, J. E. (2003). Business relationship learning and commitment in the internationalization process. Journal of International Entrepreneurship, 1(1), 83-101.

Johanson, J., \& Vahlne, J. E. (2009). The Uppsala internationalization process model revisited: From liability of foreignness to liability of outsidership. Journal of International Business Studies, 40(9), 1411-1431.

Johanson, J., \& Wiedersheim-Paul, F. (1975). The internationalisation process of the firm: Four Swedish cases. Journal of Management Studies, 12(3), 305-322.

Kedia, B. L., \& Mukherjee, D. (2009). Understanding offshoring: A research framework based on disintegration, location and externalization advantages. Journal of World Business, 44(3), 250-261.

Khanna, T., \& Palepu, K. (1999). Emerging market business groups, foreign investors, and corporate governance. NBER working paper.

Khanna, T., \& Yafeh, Y. (2007). Business groups in emerging markets: Paragons or parasites? Journal of Economic Literature, 45(2), 331-372

Kindleberger, C. P. (1969). American business abroad. New Haven: Yale University Press.

Knickerbocker, F. T. (1973). Oligopolistic reaction and the multinational enterprise. Cambridge: Harvard University Press.

Krug, B., \& Hendrischke, H., (2008). China's institutional architecture: A new institutional economics and organization theory perspective on the links between local governance and local enterprises, ERIM Report Series Research in Management ERS-2008-018-ORG, Erasmus Research Institute of Management (ERIM).

Li, S., Park, S. H., \& Li, S. (2004). Managing international business in relation-based versus rule-based countries. New York: Business Expert Press.

Liesch, P. W., Welch, L. S., \& Buckley, P. J. (2011). Risk and uncertainty in internationalisation and international entrepreneurship studies review and conceptual development. Management International Review, 51(6), 851-873.

Liu, X., Buck, T., \& Shu, C. (2005). Chinese economic development, the next stage: outward FDI? International Business Review, 14(1), 97-115.

Liu, H., \& Li, K. (2002). Strategic implication of emerging Chinese multinationals: The Haier case study. European Management Journal, 20(6), 699-706.

Lundan, S. (2010). What are ownership advantages? Multinational Business Review, 18(2), 51-69.

Makino, S., Lau, C., \& Yeh, R. S. (2002). Asset-exploitation versus asset-seeking: Implications for location choice of foreign direct investment from newly industrialized economies. Journal of International Business Studies, 33(3), 403-421.

Martin, R. (1999). The new economic geography of money. In R. Martin (Ed.), Money and the space economy (pp. 3-27). Chichester: Wiley.

McCann, P. (2011). International business and economic geography: Knowledge, time and transaction costs. Journal of Economic Geography, 11(2), 309-317.

Morck, R., Yeung, B., \& Zhao, M. (2008). Perspectives on China's outward foreign direct investment. Journal of International Business Studies, 39(3), 337-350. 
Mukherjee, S., \& Radhakrishnan, R. (2002). The Tata re-engineering co: The winds of change are sweeping through Bombay House. Get prepared to be swept away, Vol. 2008: Tata.com.

Nolan, P. (2001). China and the global business revolution. London: Palgrave.

North, Douglass. (1990). Institutions, institutional change and economic performance. Cambridge: Cambridge University Press.

Oliver, C. (1997). Sustainable competitive advantage: Combining institutional and resource based views. Strategic Management Journal, 18, 697-713.

Pangarkar, N., \& Yuan, L. (2009). Location in internationalization strategy: Determinants and consequences. Multinational Business Review, 17(2), 37-68.

Pedersen, T., \& Stucci, T. (2014). Business groups, institutional transition, and the internationalisation of firms from emerging in economies. In A. Cuervo-Cazurr \& R. Ramamurti (Eds.), Understanding multinationals from emerging markets. Cambridge: Cambridge University Press.

Pei, M. (2016). China's crony capitalism: The dynamics of regime decay. Cambridge: Harvard University Press.

Peng, M. W. (2003). Institutional transitions and strategic choices. Academy of Management Review, 28(2), 275-296.

Peng, M. W., \& Heath, P. S. (1996). The growth of the firm in planned economies in transition: Institutions, organizations, and strategic choice. The Academy of Management Review, 21(2), 492-528.

Pettis, M. (2013). The great rebalancing: Trade, conflict and the perilous road ahead for the world economy. Princeton: Princeton University Press.

Pitelis, C. N., \& Teece, D. J. (2010). Cross-border market co-creation. Dynamic capabilities and the entrepreneurial theory of the multinational enterprise. Management International Review, 47(2), $175-192$.

Roberts, S. M. (1995). Small place, big money: the Cayman Islands and the international financial system. Economic Geography, 71(3), 237-256.

Robertson, D. H. (1923). The control of industry. London: James Nisbet.

Rose, A. K., \& Spiegel, M. M. (2007). Offshore financial centres: parasites or symbionts? The Economic Journal, 117(523), 1310-1335.

Rugman, A. M., \& D’Cruz, J. R. (2000). Multinationals as flagship firms. Oxford: Oxford University Press.

Rumelt, R. P. (1984). Towards a strategic theory of the firm. In R. B. Lamb (Ed.), Competitive strategic management. Upper Saddle River: Prentice Hall.

Sauvant, K. P. (2005). New sources of FDI: The BRICS-outward FDI from Brazil, Russia, India and China. Journal of World Investment and Trade, 6(5), 639-709.

Saxenian, A. L. (2002). Transnational communities and the evolution of global production networks: The cases of Taiwan. China and India. Industry and Innovation., 9(3), 183-202.

Scott, W. R. (2002). The changing world of Chinese enterprises: An institutional perspective. In A. S. Tui \& C. M. Lau (Eds.), Management of enterprise in the People's Republic of China (pp. 59-78). Boston: Kulwer Academic Press.

Seo, B. (2011). Geographies of finance: Centers, flows, and relations. Hitotsubashi. Journal of Economics, 52, 69-86.

Shatz, H. J., \& Venables, A. J. (2003). The geography of international investment. In G. L. Clark, M. P. Feldman, \& M. S. Gertler (Hrsg.): The Oxford Handbook of Economic Geography, New York. Oxford: Oxford University Press

Shiria, S. (2002). Banks' Lending behaviour and firms' corporate financing patterns in People's Republic of China, Asian Development Bank Institute Research Paper Series 43. ADB: Tokyo.

Stevens, G. V. G. (1993). Exchange rates and foreign direct investment: A note, International Finance Discussion Papers, April, No. 444, Board of Governors of the Federal Reserve System, Washington, DC.

Subacchi, P. (2017). The people's money: How China is building a global currency. New York: Columbia University Press.

Sung, Y-W. (1996). Chinese outward investment in Hong Kong: Trends, prospects and policy implications. OECD Development Centre, Technical Papers, No. 113. Organisation for Economic Cooperation and Development. Paris.

Tan, D., \& Meyer, K. E. (2010). Business groups' outward FDI: A managerial resources perspective. Journal of International Management, 16(2), 154-164.

Tata, (2012). The website of Tata group. Mumbai. 
Teece, D. J. (2003). Knowledge and competence as strategic assets. In C. W. Holsapple (Ed.), Handbook on knowledge management 1: knowledge matters. (Chapter 7) Berlin: Springer-Verlag. In Teece 2012 op cit.

Teece, D. J. (2012). Strategy, innovation and the theory of the firm. Cheltenham: Edward Elgar.

Verbeke, A., \& Kano, L. (2015). The new internalisation theory and multinational enterprises from emerging economies: A business history perspective. Business History Review, 89(03), 415-445.

Voss, H., Buckley, P. J., \& Cross, A. R. (2009). An assessment of the effects of institutional change on chinese outward direct investment activity. In I. Alon, J. Chang, M. Fetscherin, C. Lattemann, \& J. R. McIntyre (Eds.), China rules: Globalization and political transformation (pp. 135-165). London: Palgrave Macmillan.

Voss, H., Buckley, P. J., \& Cross, A. R. (2010). The impact of home country institutional effects on the internationalisation strategy of Chinese firms. Multinational Business Review, 18(3), 25-48.

Welch, L., \& Luostarinen, H. R. (1993). Inward-outward connections in internationalization. Journal of International Marketing, 1(1), 44-56.

Williamson, O. E. (1975). Markets and hierarchies, analysis and antitrust implications: A study in the economics of internal organization. New York: Free Press.

Williamson, O. E. (1981). The economics of organisation: The transaction cost approach. The American Journal of Sociology, 87(3), 548-577.

Williamson, O. (1985). The economic institutions of capitalism. New York: The Free Press.

Witt, M. A., \& Lewin, A. Y. (2007). Outward foreign direct investment as escape response to home country institutional constraints. Journal of International Business Studies, 38(4), 579-594.

Wrigley, N. (1999). Corporate finance, leverage restructuring and the economic landscape: the LBO wave in US food retailing. In R. L. Martin (Ed.), Money and the space economy (pp. 185-205). Chichester: Wiley.

Wu, H.-L., \& Chen, C.-H. (2001). An assessment of outward foreign direct investment from China's transitional economy. Europe-Asia Studies, 53(8), 1235-1254.

Wu, F., \& Sia, Y. H. (2002). China's rising investment in South-East Asia: Trends and outlook. Journal of Asian Business, 18(2), 41-61.

Yeung, H. W.-C. (2009). Transnational corporations, global production networks and urban and regional development: A geographer's perspective on multinational enterprises and the global economy. Growth and Change, 40(2), 197-226.

Yiu, D., Bruton, G. D., \& Lu, Y. (2005). Understanding business group performance in an emerging economy: Acquiring resources and capabilities in order to prosper. SSRN eLibrary, 42(1), 183-206.

Yiu, D. W., Ng, F. W., \& Ma, X. (2013). Business group attributes and internationalisation strategy in China. Asian Business and Management, 12(1), 14-36.

Yoshihara, K. (1988). The rise of Ersatz capitalism in South East Asia. Singapore: Oxford University Press.

Zaheer, S. (1995). Overcoming the liability of foreignness. Academy of Management Journal, 38(2), 341-363.

Zeng, M., \& Williamson, P. J. (2007). Dragons at your door: How Chinese cost innovation is disrupting the rules of global competition. Boston Mass: Harvard Business School Press.

Zhan, J. X. (1995). Transnationalization and outward investment: The case of chinese firms. Transnational Corporations, 4(3), 67-100. 